\title{
High levels of T lymphocyte activation in Leishmania-HIV-1 co-infected individuals despite low HIV viral load
}

\author{
Joanna R Santos-Oliveira ${ }^{1}$, Carmem BW Giacoia-Gripp ${ }^{2}$, Priscilla Alexandrino de Oliveira ${ }^{3}$, Valdir S Amato ${ }^{4}$, \\ Jose Ângelo L Lindoso ${ }^{5}$, Hiro Goto ${ }^{5}$, Manoel P Oliveira-Neto ${ }^{6}$, Marise S Mattos ${ }^{6}$, Beatriz Grinsztejn ${ }^{6}$, \\ Mariza G Morgado², Alda M Da-Cruz ${ }^{1 *}$
}

\begin{abstract}
Background: Concomitant infections may influence HIV progression by causing chronic activation leading to decline in T-cell function. In the Americas, visceral (AVL) and tegumentary leishmaniasis (ATL) have emerged as important opportunistic infections in HIV-AIDS patients and both of those diseases have been implicated as potentially important co-factors in disease progression. We investigated whether leishmaniasis increases lymphocyte activation in HIV-1 co-infected patients. This might contribute to impaired cellular immune function.

Methods: To address this issue we analyzed $\mathrm{CD} 4^{+} \mathrm{T}$ absolute counts and the proportion of $\mathrm{CD} 8^{+} \mathrm{T}$ cells expressing CD38 in Leishmania/HIV co-infected patients that recovered after anti-leishmanial therapy.

Results: We found that, despite clinical remission of leishmaniasis, AVL co-infected patients presented a more severe immunossupression as suggested by $\mathrm{CD}^{+} \mathrm{T}$ cell counts under 200 cells $/ \mathrm{mm}^{3}$, differing from ATL/HIV-AIDS cases that tends to show higher lymphocytes levels (over 350 cells $/ \mathrm{mm}^{3}$ ). Furthermore, five out of nine, AVL/HIVAIDS presented low CD4 $4^{+} \mathrm{T}$ cell counts in spite of low or undetectable viral load. Expression of CD38 on CD8 ${ }^{+} \mathrm{T}$ lymphocytes was significantly higher in AVL or ATL/HIV-AIDS cases compared to HIV/AIDS patients without leishmaniasis or healthy subjects.

Conclusions: Leishmania infection can increase the degree of immune system activation in individuals concomitantly infected with HIV. In addition, AVL/HIV-AIDS patients can present low CD4 ${ }^{+} \mathrm{T}$ cell counts and higher proportion of activated T lymphocytes even when HIV viral load is suppressed under HAART. This fact can cause a misinterpretation of these laboratorial markers in co-infected patients.
\end{abstract}

\section{Background}

Leishmania/HIV-1 co-infection has been considered an emerging disease mainly due to the expansion of the AIDS epidemic over leishmaniasis endemic areas and vice-versa [1]. Visceral leishmaniasis associated-HIV/ AIDS is well known as an opportunistic disease especially in the Mediterranean basin [1]. However, an increasing number of reports of tegumentary leishmaniasis-HIV/AIDS patients underlines the importance of this additional association [2-6]. In America, vector

\footnotetext{
* Correspondence: alda@ioc.fiocruz.br

'Laboratório Interdisciplinar de Pesquisas Médicas, Instituto Oswaldo Cruz

-FIOCRUZ. Av. Brasil 4365. Rio de Janeiro, CEP 21040-360, Brazil

Full list of author information is available at the end of the article
}

sandflies and Leishmania species that cause American visceral leishmaniasis (AVL) and tegumentary leishmaniasis (ATL) differ from those observed in other endemic regions around the world. This could result in the particular clinical features observed in HIV-co-infected patients in the New World [3,7]. In Brazil, both Leishmania and HIV infection are endemic and this co-infection is becoming an important public health problem $[1,7]$.

The clinical outcome of both AVL and ATL is dependent on the Leishmania-specific immune response. This influence can be exerted in many different ways. AVL is a systemic infection affecting lymphoid organs; it is associated with parasite antigens driving an impaired

\section{Biomed Central}


T-cell response leading to a depletion of bone marrow as well as systemic $\mathrm{CD} 4^{+}$and $\mathrm{CD} 8^{+} \mathrm{T}$ lymphocytes. Profound immunosuppression is the consequence [8-11]. In contrast, ATL is a benign disease which affects skin and mucous membranes. In these ATL patients, the specific immune response is preserved though not well regulated, leading to tissue damage $[10,12]$. Even considering the differences in the clinical and immunopathogenesis of those AVL and ATL, T lymphocyte function is affected in both diseases, and the clinical cure is achieved by restoration of an adequate effector immune response [9-12].

Earlier studies have shown that Leishmania infection can promote HIV-1 replication in vitro [13] and in vivo [14]. Beside this, HIV-1 infection impairs macrophage ability to control intracellular protozoans, enabling Leishmania growth $[15,16]$. While highly effective antiretroviral therapy (HAART) has been shown to decrease significantly the incidence of leishmaniasis in HIVinfected patients $[17,18]$, it does not seem to prevent relapses [19]. This suggests that maintenance of the parasite can impact the pathogenesis of both diseases.

Low lymphocyte recall responses after parasite stimulation but preserved IFN- $\gamma$ production in ATL-HIV-AIDS patients were already demonstrated [3]. On the other hand, high type 2 cytokines levels are observed in HIV/ AIDS associated AVL, potentially favoring the dissemination of both the virus and Leishmania [14]. Moreover, increased levels of CCR5 molecules on $\mathrm{CD}^{+}$lymphocytes were also observed in AVL/HIV-AIDS [20], suggesting that Leishmania infection could favor HIV-1 entry into its target cells through this receptor. Immunological studies reporting Leishmania/HIV co-infection generally involve patients with active disease $[3,14,20,21]$, but the mechanisms that maintain leishmaniasis in remission, and by consequence the factors that predispose the parasite reactivation are poorly understood.

Chronic activation of the immune system has been considered an important mechanism related to declining lymphocytic functions and has become an important tool for monitoring HIV-1 infected patients [22]. The proportion of $\mathrm{CD}^{+} \mathrm{T}$ cells that express $\mathrm{CD} 38^{+}$, a surrogate of activation marker, can predict the subsequent decline of the $\mathrm{CD}_{4}{ }^{+} \mathrm{T}$ cell population [23] and was correlated with high viral load levels in HIV infected individuals [24]. Actually, the degree of cellular activation, evidenced by the co-expression of CD38 and HLA-DR on $\mathrm{T}$ lymphocytes has been considered an important predictor of disease progression [25]. Concomitant infections can exert an impact on viral replication by contributing to an increase in $\mathrm{T}$ lymphocyte activation already seen in HIV patients [26]. In accordance with this, co-infection with HIV and tuberculosis results in high levels of CD38 on $\mathrm{CD}^{+} \mathrm{T}$ cells [27]. Nevertheless, viral infections concomitant with HIV-1 infection seem to have different effects on $\mathrm{T}$ lymphocyte activation. Recent evidence showed that Hepatitis C virus/HIV-1 co-infected patients presented elevated immune activation levels, despite effective antiretroviral therapy [28]. On the other hand, GB virus type $C$ replication has been associated to lower $\mathrm{T}$ cell activation, which has considered a protective mechanism involved in the HIV1 disease progression [29]. No influence of human herpesvirus replication on cell activation has been observed [30]. However, the impact of Leishmania infection on T cell perturbation due to HIV-1 is still unclear." We hypothesized that Leishmania infection could be an additional factor for lymphocyte activation and lead to impaired effect or immune function, favoring parasite replication and, consequently, frequent relapses. Therefore, we investigated whether leishmaniasis could impact T lymphocytes activation in HIV-1 co-infected patients through the analysis of $\mathrm{CD} 4^{+} \mathrm{T}$ absolute counts and of the proportion of $\mathrm{CD}^{+} \mathrm{T}$ cells expressing CD38 in Leishmania/HIV co-infected patients recovered after anti-leishmanial therapy.

\section{Methods}

\section{Patients and Subjects}

Seventeen HIV-Leishmania co-infected patients (AVLHIV/AIDS - 9 cases and ATL-HIV/AIDS - 8 cases) were enrolled for this study. Patients were in the remission phase, minimum six months after the end of their anti-Leishmania treatment and had no signs or symptoms of active leishmaniasis (Table 1). Sixteen HIV-1/ AIDS cases, without previous leishmaniasis paired with co-infected patients by viral load (HIV RNA copies/mL: $<400,>400$ to 10.000 and over $>10,000$ copies $/ \mathrm{mL}$ ) and eight healthy volunteers were included as controls. HIV/AIDS patients were receiving antiretroviral therapy for at least one year, according to the Brazilian guidelines. Informed consent was obtained from all participants. The study was approved by the Fundação Oswaldo Cruz and IPEC Ethical Committees.

\section{Immunologic and virologic assessments}

To determinate the absolute counts of $\mathrm{CD} 4^{+} \mathrm{T}$ and $\mathrm{CD} 8$ $+\mathrm{T}$ lymphocytes, a BD Tritest ${ }^{\circ}$ monoclonal antibody specific for CD4/CD8/CD3 conjugated to FITC, PE and PerCP, respectively and BDTrue Count ${ }^{\circ}$ reagent kit was used according to the manufacturer's instructions (BD Biosciences, Franklin Lakes, NJ, USA). Samples were acquired using a FACSCalibur ${ }^{\circ}$ (BD, USA) and analysed by Multiset ${ }^{\circ}$ software (BD, USA). Plasma HIV-1 RNA levels were quantified using the branched DNA assays (Siemens, Versant HIV-1 RNA 3.0, Tarrytown, NY, USA). The lower limit of detection for this assay was 50 copies $/ \mathrm{mL}$. 
Table 1 Clinical and laboratorial characteristics of HIV-1 co-infected leishmaniasis patients and control groups

\begin{tabular}{|c|c|c|c|c|}
\hline Parameters & $\begin{array}{l}\text { AVL/HIV-1 patients } \\
(\mathrm{n}=9)\end{array}$ & $\begin{array}{l}\text { ATL/HIV-1 patients } \\
(\mathrm{n}=8)\end{array}$ & $\begin{array}{c}\text { HIV-1 } \\
\text { infected* } \\
(n=16)\end{array}$ & $\begin{array}{l}\text { Healthy subjects } \\
\qquad(\mathrm{n}=8)\end{array}$ \\
\hline Age, years, (median) & $38(35-50)^{\mathrm{a}}$ & $44(38-54)^{b}$ & $39(33-49)^{c}$ & $26(25-30)^{\mathrm{abc}}$ \\
\hline Male sex, n, (\%) & $9(100)^{d}$ & $8(100)^{\mathrm{e}}$ & $15(94)^{f}$ & $4(50)^{\text {def }}$ \\
\hline $\mathrm{CD}^{+} \mathrm{T}$ Cell count, cells $/ \mathrm{mm}^{3}$ & $62(52-127)^{9}$ & $404(294-597)^{h}$ & $380(223-450)^{i}$ & $1,106(957-1,300)^{g h i}$ \\
\hline Current AIDS diagnosis, Number of cases (\%) & $9(100)$ & $6(75)$ & $8(50)$ & - - \\
\hline Time of clinical remission of leishmaniasis, months & $8(6-12)$ & $11(7.5-14)$ & -— & -— \\
\hline Patients with undetectable viremia, (\%) & $5(55.6)$ & $4(50)$ & $9(56.2)$ & - - \\
\hline $\begin{array}{l}\text { Viral load levels of patients with } \\
\text { detectable viremia, copies } / \mathrm{mL}\end{array}$ & $142,240(24,025-279,321)$ & $6,200(2,012-78,176)$ & $12,010(2,000-136,625)$ & -— \\
\hline
\end{tabular}

$\mathrm{N}=$ number, AVL - American visceral leishmaniasis, ATL - American tegumentary leishmaniasis *HIV-1 infected patients without leishmaniasis Note: Data are median (interquartile range) values, except for current AIDS diagnosis.

Patients $\times$ Health subjects $(a-p<0.001 ; b / c-p<0.01 ; d / e / f \times$ def $-p<0.05), g / h / i \times g h i-p<0.001 ; g \times h-p<0.01 ; g \times i-p<0.01$.

\section{Obtainment of peripheral blood mononuclear cells (PBMC) and immune activation}

PBMC were separated by centrifugation over a gradient of Ficoll-Hypaque (Histopaque 1077; Sigma Chemical Company, St. Louis, MO, USA) and ressuspended in phosphate-buffered saline (PBS) containing $0,1 \%$ of sodium azide (Sigma, USA). PBMCs were adjusted to $10^{5}$ cells and labeled with anti-CD8 FITC plus anti-CD38 PE monoclonal antibodies (BD Simultest ${ }^{\mathrm{Tm}}, \mathrm{BD}$ Biosciences, San Jose, CA, USA). After incubation, the cells were fixed with PBS plus 1\% paraformaldehyde. At least 10,000 events were acquired using a FACSCalibur and phenotypic analysis was carried out by using CellQuest $^{\text {Ts }}$ software (BD). Although the validated marker of $\mathrm{CD}^{+} \mathrm{T}$ cell activation is the co-expression of CD38 and HLA DR, we used the detection of CD38 in $\mathrm{CD}^{+}$as a surrogate of this validated marker [25]. CD38 positivity was determined on $\mathrm{CD}^{+} \mathrm{T}$ cell populations inside the gate previously established for $\mathrm{TCD}^{+}$and expressed as a percentage of CD38 in CD8 ${ }^{\text {high }}$.

\section{Statistical analysis}

The values were expressed as medians and interquartile range. Statistical analysis was performed using the Mann-Whitney U test (GraphPad Prism, version 4.0, San Diego, CA, USA). Multivariate linear regression analysis (SPSS software, version 9.0) was used to determine influence that of intervenient factors on the percentage of $\mathrm{CD}^{+} \mathrm{T}$ cells expressing CD38 (dependent variable). Absolute counts of $\mathrm{CD}^{+} \mathrm{T}$ cells, viral load (undetectable or detectable) and Leishmania infection (presence or absence) were considered as independent variables. Statistically significant differences were considered when $p<0.05$.

\section{Results}

Clinical and laboratory characteristics are depicted in Table 1 and 2. AVL-HIV/AIDS patients in clinical remission showed significantly ( $\mathrm{p}<0.001$ ) lower numbers of $\mathrm{CD}^{+} \mathrm{T}$ lymphocytes in comparison to HIV-1 infected patients without leishmaniasis, (Figure 1A and Table 1). In contrast, $\mathrm{CD}^{+} \mathrm{T}$ counts in ATL-HIV/AIDS patients were similar to HIV-1 infected patients without leishmaniasis (Figure 1A). Both types of co-infected patients and the HIV-1 infected patients without leishmaniasis had much lower levels of $\mathrm{CD}_{4}^{+} \mathrm{T}$ counts when compared to healthy donors ( $p<0.001$, Figure $1 \mathrm{~A})$.

HIV-1 viral load in AVL/HIV-AIDS was not correlated with $\mathrm{CD}^{+} \mathrm{T}$ cell count, since low or undetectable levels of HIV-1 were seen even in patients with very low $\mathrm{CD}^{+} \mathrm{T}$ cells counts (Figure $1 \mathrm{~B}$ ). By contrast, ATL/HIVAIDS patients in clinical remission had higher $\mathrm{CD}^{+} \mathrm{T}$ cell numbers and exhibited the lowest HIV plasma viral load (Figure 1B).

HIV-1 co-infected individuals (AVL and ATL), had a significantly higher percentage of $\mathrm{CD}^{+} \mathrm{T}$ cells that expressed CD38 when compared to HIV-1 infected patients without leishmaniasis (median 55.8\%; [49\% $64 \%$ ], $\mathrm{p}<0.05$ ) (Figure 1C). However, the frequency of CD38 expressed by the $\mathrm{CD}^{+} \mathrm{T}$ cell subset was much higher in AVL/HIV-AIDS cases (median 93.5\%, [87\%97.9\%]) than in patients with ATL/HIV-AIDS (median $77 \%$, [69\%-83.6\%], p < 0.001). Healthy blood donors showed the lowest levels of $\mathrm{CD}^{+} \mathrm{T}$ cell activation $\left(\mathrm{CD} 8^{+}\right.$on $\mathrm{CD}^{+} \mathrm{T}$ cells $=$ median $31.2 \%$; [24\%-35.6\%], $\mathrm{p}<0.001$ ) (Figure 1C). There was no correlation between the percentages of CD38 on $\mathrm{CD}^{+} \mathrm{T}$ cell and plasma HIV-1 viral load (Table 3), since high levels of activation were observed despite viral load levels in the co-infected patients (Figure 1D). HIV-1 infected controls presented a positive correlation between the viral load and cellular activation $(\mathrm{p}=0.01, \mathrm{r}=0.60$, data not show).

A multivariate statistical analysis showed a significant positive correlation between Leishmania infection and the levels of CD38 on CD38 T lymphocytes ( $<<0.001)$, 
Table 2 CD4+ T cell counts and viral load levels of HIVAIDS associated leishmaniasis patients (visceral or tegumentary) and HIV-1 infected control group

\begin{tabular}{|c|c|c|}
\hline $\begin{array}{l}\text { Patient's } \\
\text { Number }\end{array}$ & $\begin{array}{c}\mathrm{CD}^{+} \mathrm{T} \text { cells counts(cells/ } \\
\mathrm{mm}^{3} \text { ) }\end{array}$ & $\begin{array}{l}\text { Viral load levels } \\
\text { (copies } / \mathrm{mL} \text { ) }\end{array}$ \\
\hline \multicolumn{3}{|c|}{ VL/HIV-AIDS } \\
\hline 1 & 78 & $<400$ \\
\hline 2 & 59 & 5,810 \\
\hline 3 & 33 & 316,402 \\
\hline 4 & 129 & $<400$ \\
\hline 5 & 61 & $<400$ \\
\hline 6 & 45 & 242,240 \\
\hline 7 & 187 & $<400$ \\
\hline 8 & 124 & 42,240 \\
\hline 9 & 68 & $<400$ \\
\hline \multicolumn{3}{|c|}{ TL/HIV-AIDS } \\
\hline 1 & 367 & 1,700 \\
\hline 2 & 440 & $<400$ \\
\hline 3 & 512 & 2,324 \\
\hline 4 & 86 & 146,351 \\
\hline 5 & 541 & $<400$ \\
\hline 6 & 345 & $<400$ \\
\hline 7 & 576 & $<400$ \\
\hline 8 & 242 & 10,000 \\
\hline \multicolumn{3}{|c|}{ HIV-1 infected } \\
\hline 1 & 146 & 136,625 \\
\hline 2 & 543 & $<400$ \\
\hline 3 & 215 & $<400$ \\
\hline 4 & 34 & 12,010 \\
\hline 5 & 230 & 253,761 \\
\hline 6 & 609 & $<400$ \\
\hline 7 & 391 & $<400$ \\
\hline 8 & 491 & $<400$ \\
\hline 9 & 377 & $<400$ \\
\hline 10 & 73 & 1,750 \\
\hline 11 & 371 & 10,000 \\
\hline 12 & 236 & $<400$ \\
\hline 13 & 635 & $<400$ \\
\hline 14 & 382 & 2,000 \\
\hline 15 & 394 & 55,239 \\
\hline 16 & 410 & $<400$ \\
\hline
\end{tabular}

independently of $\mathrm{CD}_{4}^{+} \mathrm{T}$ counts and HIV viremia (Table 3). A covariance was not performed because of the low number of ATL and AVL patients.

\section{Discussion}

Leishmania can persist in the host after treatment and may further reactivate under immunossupression [1]. A host parasite dynamic equilibrium does not seem to be reached in HIV co-infected patients probably because immunosupressed patients are not able to mount an efficient T-cell response to control Leishmania, resulting

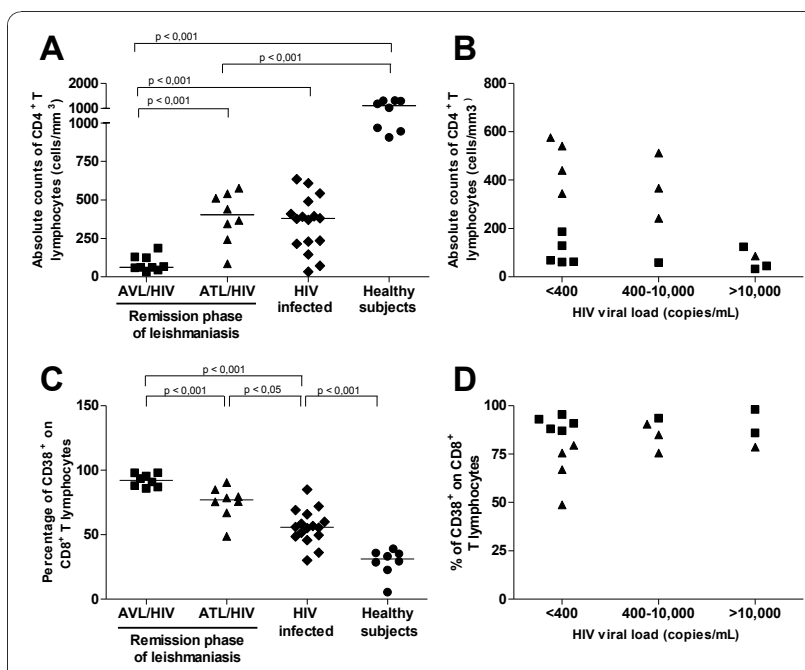

Figure 1 Relationship between lymphocyte immune status and plasmatic HIV-1 viral load in Leishmania/HIV-1 co-infected patients during remission phase of leishmaniasis. A. Absolute counts of $\mathrm{CD}^{+} \mathrm{T}$ lymphocytes. $\mathbf{B}$. Absolute counts of $\mathrm{CD} 4^{+} \mathrm{T}$ lymphocytes and viral load levels. C. Levels of CD38 expression on CD8 ${ }^{+} \mathrm{T}$ lymphocytes. D. CD38 expression on CD8 ${ }^{+} \mathrm{T}$ lymphocytes and viral load levels. American visceral leishmaniasis (AVL)/HIV-AIDS patients (solid squares), American tegumentary leishmaniasis (ATL)/ HIV-AIDS patients (solid triangles), HIV-1 infected adults without leishmaniasis (HIV infected, solid diamonds) and healthy subjects (solid circles). Each point represents one subject. The horizontal bars express median.

in frequent relapses especially in AVL but also in ATL $[1,5]$. We found that despite clinical remission of protozoan disease, AVL co-infected patients were more severely immunossupressed than ATL co-infected patients. Furthermore, lymphocyte activation status was higher in both groups of co-infected patients than in HIV-1-infected patients without leishmaniasis. Our results suggest that Leishmania infection increases the degree of the immune system activation in individuals concomitantly infected with HIV-1. This phenomena

Table 3 Multivariate linear regression analysis to evaluate the association between $\mathrm{T}$ cell activation (CD38 + on CD8+ T lymphocytes) and independent variables in leishmaniasis and HIV-1 co-infected patients

\begin{tabular}{lccc}
\hline Independent variables & \multicolumn{3}{c}{$\begin{array}{c}\text { Dependent variable } \\
\text { Percentage of CD38 } \\
\text { lymphocytes }\end{array}$} \\
\hline & Coef $^{\mathbf{1}}$ & SE $^{+} \mathbf{~ T}$ \\
Leishmania infection & 24.88 & 4.63 & P \\
(presence or absence) & & & 0.000011 \\
CD4 $^{+}$T cell count, cells/mm & & \\
Viral load levels & -0.02 & 0.013 & 0.13 \\
(detectable or undetectable) & 4.12 & 4.85 & 0.39
\end{tabular}

1 Coef - Correlation coefficient, 2 SE - Standard error

Obs. HIV-1 infected patients were also included in this analysis. 
can affect immune effector function and may constitute an additional mechanism for explain relapses.

Both AVL and ATL tend to emerge as opportunistic diseases in HIV infected patients without leishmaniasis especially in those presenting with $\mathrm{CD}_{4}^{+} \mathrm{T}$ cell levels below 350 cells $/ \mathrm{mm}^{3}$ [1,4,5,31,32]. In this study, AVL/ HIV-AIDS patients presented very low $\mathrm{CD}^{+} \mathrm{T}$ cell levels during remission of clinical symptoms after successful anti-leishmanial therapy and under HAART use. This was not observed in ATL/HIV-AIDS. The low CD $4^{+} \mathrm{T}$ cell counts observed in AVL co-infected patients cannot be solely explained by lymphocyte depletion related to HIV-1 replication, since low $\mathrm{CD} 4^{+} \mathrm{T}$ cell counts were observed in AVL/HIV-AIDS patients with undetectable or low viral load levels. Additionally, CD4 T cell depletion of bone marrow caused by both HIV infection [33] and AVL $[9,11]$ was already demonstrated and may lead to deficiencies in the input of new lymphocytes into the periphery. These factors could explain why AVL/HIVAIDS patients already had CD4 cell counts lower than 200 cells $/ \mathrm{mm}^{3}$ at the beginning of anti-leishmanial therapy (data not shown), which additionally could contribute to the maintenance of low levels during remission phase. By contrast, the immunopathogenesis of ATL/ HIV-AIDS may not be related to systemic imunossuppression since ATL is more restricted to the tegument and the draining lymph nodes. In this connection, these ATL/HIV-AIDS patients in remission phase apparently recovered their lymphocyte levels (data not shown) since they have much higher $\mathrm{CD} 4^{+} \mathrm{T}$ cell counts than those previously observed in patients with active disease [3-5].

In the present study we have shown that leishmaniasis/ HIV-AIDS patients displayed elevated levels of CD38 on $\mathrm{CD}^{+} \mathrm{T}$ cells levels in relation to HIV-1 infected patients without leishmaniasis. This implies that concomitant Leishmania infection could contribute to enhance the activation induced by HIV antigens as has been described in tuberculosis [27] and hepatitis C virus [28]. The finding of high CD38 levels positively correlated with Leishmania infection reinforces the idea that leishmaniasis can be a cofactor to of this heightened activation status. It is known that high activation levels are inversely proportional to the $\mathrm{CD} 4^{+} \mathrm{T}$ cell levels, suggesting that activation could also contribute to the $\mathrm{T}$ cell depletion [22,25,34]. Interestingly, CD38 levels observed in co-infected patients were much higher than those seen in cured AVL and ATL patients without HIV/AIDS (unpublished data). This result raises the possibility that parasite persistence might have a role in this activation process, since released Leishmania antigens can stimulate lymphocytes. The frequent relapses described in AVL/HIV-AIDS, which occur more frequently than in ATL/HIV-AIDS patients, could be evidence of this reduced ability to maintain the parasite under control due to the impaired immune function $[4,19]$. Viscerotropic
Leishmania species in the bone marrow promote immunological damage to a greater extent than dermotropic parasites do in the skin $[4,11]$.

This could be, at least in part, why activation levels were higher in AVL/HIV-AIDS than in ATL/HIV-AIDS patients.

\section{Conclusion}

Taken together, our results point to co-infection with leishmaniasis as a factor that is likely to increase the severity of immunodeficiency caused by HIV, especially in AVL/HIV-AIDS patients. The low T CD4 cell counts among those patients with AVL/HIV-AIDS after remission, even in the absence of detectable viral load may have important implications for the HAART monitoring. Furthermore, the prognostic value of CD38 expression on $\mathrm{CD}^{+} \mathrm{T}$ cells might not be useful in predicting HIV-1 progression in co-infected patients [35] since these molecules levels stay elevated after clinical remission of leishmaniasis. To our knowledge no previous study has evaluated the degree of immune activation in Leishmania/HIV-1 coinfected patients. Further studies evaluating the consequences of high levels of cellular activation will be of great interest as immunological abnormalities in $\mathrm{T}$ lymphocyte function can impact the clinical course of both infections.

\section{Acknowledgements}

We are very grateful to Dr. David Watkins for helpful discussions and for critical reviewing of this manuscript. To thanks Dr. Alvaro Bertho to assistance with flow cytometric analysis and helpful advices, to Dr. José Henrique Pilotto, to Dr. Sandra Wagner and to Ricardo Nogueira for helping with recruitment of HIV-1 patients and co-infected patients. To Dr. Filipe Carvalho-Costa for helpful assistance with statistical analysis. We would like to thank the following funding agencies for support of our work: Programa Nacional de DST/AIDS, Ministério da Saúde (grant ED00095/2007) and Instituto Oswaldo Cruz (internal funds). JRSO is a fellowship of CNPq. AMC is a researcher fellowship from CNPq and FAPERJ.

\section{Author details}

'Laboratório Interdisciplinar de Pesquisas Médicas, Instituto Oswaldo Cruz -FIOCRUZ. Av. Brasil 4365. Rio de Janeiro, CEP 21040-360, Brazil. ²Laboratório de Aids e Imunologia Molecular; Instituto Oswaldo Cruz - FIOCRUZ, Av. Brasil 4365. Rio de Janeiro, CEP 21040-360, Brazil. ${ }^{3}$ Hospital-Dia Profa. Esterina Corsini, Hospital Universitário, Universidade Federal de Mato Grosso do Sul (UFMS). Mato Grosso do Sul, CEP 79070-900, Brazil. "4Serviço de Doenças Infecciosas e Parasitárias, Faculdade de Medicina, Universidade de São Paulo, São Paulo, Brazil. CEP 05403-010, São Paulo, Brazil. ${ }^{5}$ Instituto de Medicina Tropical de São Paulo - Universidade de São Paulo, São Paulo, CEP 05403010, Brazil. ${ }^{6}$ Instituto de Pesquisa Clínica Evandro Chagas, IPEC - FIOCRUZ, Av. Brasil 4365. Rio de Janeiro, CEP 21040-360, Brazil.

\section{Authors' contributions}

JRSO, AMC participated in the conception and design of the study; analysis and interpretation of data, drafting the paper, CBGG and MGM - participated in the conception and design of the study, analysis and interpretation of data, or substantially revising it. PAO, VSA, JALL, HG, MPON, MSM and BG participated in the recruitment and follow up of the patients of this study. All authors read and approved the final manuscript.

\section{Competing interests}

None of the authors has any potential financial conflict of interest related to this manuscript. 
Received: 26 January 2010 Accepted: 20 December 2010

Published: 20 December 2010

\section{References}

1. Alvar J, Aparicio P, Aseffa A, Den Boer M, Cañavate C, Dedet JP, Gradoni L, Ter Horst R, López-Vélez R, Moreno J: The relationship between leishmaniasis and AIDS: the second 10 years. Clin Microbiol Rev 2008, 21:334-359.

2. Coura JR, Galvão-Castro B, Grimaldi G: Disseminated American cutaneous leishmaniasis in a patient with AIDS. Mem Inst Oswaldo Cruz 1987, 82:581-582.

3. Da-Cruz AM, Mattos M, Oliveira-Neto MP, Coutinho Z, Machado ES, Coutinho SG: Cellular immune responses to Leishmania braziliensis in patients with AIDS-associated American cutaneous leishmaniasis. Trans $R$ Soc Trop Med Hyg 2000, 94:569-571.

4. Couppié P, Clyti E, Sobesky M, Bissuel F, Del Giudice P, Saint-Marie D, Debret JP, Carme B, Pradinaud D: Comparative study of cutaneous leishmaniasis in human immunodeficiency virus (HIV)-infected patients and non-HIV-infected patients in French Guiana. Br J Dermatol 2004, 151:1165-1171.

5. Lindoso JA, Barbosa RN, Posada-Vergara MP, Duarte MI, Oyafuso LK, Amato VS, Goto H: Unusual manifestations of tegumentary leishmaniasis in AIDS patients from the New World. Br J Dermatol 2009, 160:311-318.

6. Padovese V, Terranova M, Toma L, Barnabas GA, Morrone A: Cutaneous and mucocutaneous leishmaniasis in Tigray, northern Ethiopia: clinical aspects and therapeutic concerns. Trans R Soc Trop Med Hyg 2009, 103:707-711.

7. Rabello A, Orsini M, Disch J: Leishmania/HIV co-infection in Brazil: an appraisal. Ann Trop Med Parasitol 2003, 97:S17-S28.

8. Carvalho EM, Bacellar O, Barral A, Badaró R, Johnson WD Jr: Antigenspecific immunosupression in visceral leishmaniasis is cell mediated. J Clin Invest 1989, 83:860-864.

9. Saha S, Mondal S, Banerjee A, Ghose J, Bhowmick S, Ali N: Immune responses in kala-azar. Indian J Med Re 2006, 123:245-266.

10. Schriefer A, Wilson ME, Carvalho EM: Recent developments leading toward a paradigm switch in the diagnostic and therapeutic approach to human leishmaniasis. Curr Opin Infect Dis 2008, 21:483-488.

11. Goto H, Prianti MG: Immunoactivation and immunopathogeny during active visceral leishmaniasis. Rev Inst Med Trop São Paulo 2009, 51:241-246.

12. Da-Cruz AM, Bittar R, Mattos M, Oliveira-Neto MP, Nogueira R, PinhoRibeiro V, Azeredo-Coutinho RB, Coutinho SG: T-cell-mediated immune responses in patients with cutaneous or mucosal leishmaniasis: longterm evaluation after therapy. Clin Diagn Lab Immunol 2002, 9:251-256.

13. Zhao C, Papadopoulou B, Tremblay MJ: Leishmania infantum enhances human immunodeficiency virus type-1 replication in primary human macrophages through a complex cytokine network. Clin Immunol 2004, 113:81-88

14. Cacopardo B, Nigro L, Preiser W, Fama A, Satariano MI, Braner J, Celesia BM, Weber B, Russo R, Doerr HW: Prolonged Th2 cell activation and increased viral replication in HIV-Leishmania co-infected patients despite treatment. Trans R Soc Trop Med Hyg 1996, 90:434-435.

15. Wolday D, Akuffo H, Fessahaye G, Valentine A, Britton S: Live and killed human immunodeficiency virus type-1 increases the intracellular growth of Leishmania donovani in monocyte-derived cells. Scand I Infect Dis 1998, 30:29-34.

16. Barreto de Souza V, Pacheco GJ, Silva AR, Castro-Faria-Neto HC, Bozza PT, Saraiva EM, Bou-Habbib DC: Increased Leishmania replication in HIV-1infected macrophages is mediated by tat protein through cyclooxygenase-2 expression and prostaglandin E2 synthesis. J Infect Dis 2006, 194:846-854

17. Lopez-Velez R, Casado J, Pintado V: Decline of a visceral leishmaniasis epidemic in HIV-infected patients after the introduction of highly active antiretroviral therapy (HAART). Clin Microbiol Infect 2001, 7:394-395.

18. Del Giudice P, Mary-Krause M, Pradier C, Grabar S, Dellamonica P, Marty P, Gastaut JA, Costagliola D, Rosenthal E, the clinical Group of the French Hospital Database on HIV: Impact of highly active antiretroviral therapy on the incidence of visceral leishmaniasis in aFrench Cohort of patients infected with human immunodeficiency virus. J Infect Dis 2002, 186:1366-1370.

19. Casado JL, Lopez-Velez R, Pintado V, Quereda C, Antela A, Moreno S: Relapsing visceral leishmaniasis in HIV-infected patients undergoing successful protease inhibitor therapy. Eur I Clin Microbiol Infect Dis 2001, 20:202-205.

20. Nigro L, Rizzo ML, Vancheri C, La rosa R, Mastruzzo C, Tomaselli V, Ragusa A, Manuele R, Cacopardo B: CCR5 and CCR3 expression on $\mathrm{T} \mathrm{CD3}^{+}$ lymphocytes from HIV/Leishmania co-infected subjects. Med Microbiol Immunol 2007, 196:253-255.

21. Preiser W, Cacopardo B, Nigro L, Braner J, Nunnari A, Doerr HW, Weber B: Immunological findings in HIV-Leishmania coinfection. Intervirology 1996, 39:285-288.

22. Grossman Z, Meier-Schellersheim M, Paul WE, Picker L: Pathogenesis of HIV infection: what the virus spare is as important as what it destroys. Nat Med 2006, 12:289-295.

23. Bofill M, Mocroft A, Lipman M, Medina E, Borthwick NJ, Sabin CA, Timms A, Winter M, Baptista L, Johnson MA, Lee CA, Phillips AN, Janossy G: Increased numbers of primed activated $\mathrm{CD} 8^{+} \mathrm{CD} 38^{+} \mathrm{CD} 45 \mathrm{RO}{ }^{+} \mathrm{T}$ cells predict the decline of CD4 ${ }^{+} \mathrm{T}$ cells in HIV-infected patients. AIDS 1996, 10:827-834.

24. Benito JM, Lopez M, Lozano S, Martinez P, Gonzalez-Lahoz J, Soriano V: $\mathrm{CD} 38$ expression on $\mathrm{CD}^{+}{ }^{+}$lymphocytes as a marker of residual virus replication in chronically HIV-infected patients receiving antiretroviral therapy. AIDS Res Hum Retroviruses 2004, 20:227-233.

25. Douek D, Roederer M, Koup R: Emerging concepts in the immunopathogenesis of AIDS. Annu Rev Med 2009, 60:471-484

26. Bentwich Z, Kalinkovich A, Weisman Z: Immune activation is a dominant factor in the pathogenesis of African AIDS. Immunol Today 1995, 16:187-191.

27. Rodrigues DS, Cunha RM, Kallas EG, Salomão R: Distribution of naive/ effector $\mathrm{CD}^{+} \mathrm{T}$ lymphocytes and expression of $\mathrm{CD} 38$ on $\mathrm{CD} 8^{+} \mathrm{T}$ lymphocytes in AIDS patients with tuberculosis. Braz J Infect Dis 2003, 7:161-165.

28. Gonzalez VD, Falconer K, Blom KG, Reichard O, Mørn B, Laursen AL, Weis N, Alaeus A, Sandberg JK: High levels of chronic immune activation in the Tcell compartments of patients coinfected with hepatitis $C$ virus and human immunodeficiency virus type 1 and on highly active antiretroviral therapy are reverted by alpha interferon and ribavirin treatment. J Virol 2009, 83:11407-11411.

29. Maidana-Giret MT, Silva TM, Sauer MM, Tomiyama H, Levi JE, Bassichetto KC, Nishiya A, Diaz RS, Sabino EC, Palacios R, Kallas EG: GB virus type C infection modulates T-cell activation independently of HIV-1 viral load. AIDS 2009, 23:2277-2287.

30. Jacobson MA, Ditmer DP, Sinclair E, Martin JN, Deeks SG, Hunt P, Mocarski ES, Shiboski C: Human herpesvirus replication and abnormal $\mathrm{CD}^{+} \mathrm{T}$ cell activation and low $\mathrm{CD}^{+} \mathrm{T}$ cell counts in antiretroviralsuppressed HIV-infected patients. Plos One 2009, 4:e5277.

31. Mattos M, Caiza A, Fernandes O, Gonçalves AJS, Pirmez C, Souza CSF, Oliveira-Neto MP: American cutaneous leishmaniasis associated with HIV infection: report of four cases. J Eur Acad Dermatol Venerol 1998, 10:218-225.

32. Daher ED, Fonseca PP, Gerhard ES, Silva Leitão TD, Silva GB Junior: Clinical and epidemiological features of visceral leishmaniasis and HIV coinfection in 15 patients from Brazil. J Parasitol 2008, 2:1.

33. McCune JM: The dynamics of $\mathrm{CD}^{+}{ }^{+} \mathrm{T}$-cell depletion in HIV disease. Nature 2001, 410:974-979.

34. Benito JM, López M, Lozano S, González-Lahoz J, Soriano V: Downregulation of interleukin-7 receptor (CD127) in HIV infection is associated with $\mathrm{T}$ cell activation and is a main factor influencing restoration of CD4(+) cells after antiretroviral therapy. J Infect Dis 2008, 198:1466-73

35. Liu Z, Cumberland WG, Hultin LE, Prince HE, Detels R, Giorgi JV: Elevated $\mathrm{CD} 38$ antigen expression on $\mathrm{CD} 8^{+} \mathrm{T}$ cells is a stronger marker for the risk of chronic HIV disease progression to AIDS and death in the Multicenter AIDS Cohort Study than $\mathrm{CD}^{+}$cell count, soluble immune activation markers, or combinations of HLA-DR and CD38 expression. J Acquir Immune Defic Syndr Hum Retrovirol 1997, 16:83-92.

\section{Pre-publication history}

The pre-publication history for this paper can be accessed here: http://www.biomedcentral.com/1471-2334/10/358/prepub

doi:10.1186/1471-2334-10-358

Cite this article as: Santos-Oliveira et al:: High levels of T lymphocyte activation in Leishmania-HIV-1 co-infected individuals despite low HIV viral load. BMC Infectious Diseases 2010 10:358. 